\title{
Editors' message: The housing crisis from underground-damage to a historic town by geothermal drillings through anhydrite, Staufen, Germany
}

\author{
Nico Goldscheider • Timothy D. Bechtel
}

Keywords Geothermal drilling · Anhydrite · Germany

Geothermal energy can be used for heating, electric power generation and other applications (e.g. Seyboth et al. 2008). The confidence of the public in this technology is currently compromised by several bad examples where inappropriate implementation of geothermal installations has caused avoidable damage. A dramatic but instructive case is presented here. This article is a plea both for the reasonable use of geothermal energy and for more geologic and hydrogeologic competence and education in geothermics.

Connoisseurs of classical German literature know the historic town of Staufen (7,800 inhabitants; Fig. 1) as the town of Doctor Faust, immortalised by the eponymous drama written by Johann Wolfgang von Goethe (17491832). The town is currently suffering severe damage that began immediately following geothermal drillings in the city centre.

Staufen is located in the Upper Rhine Graben, within the tectonic transition zone between the central graben and the Black Forest. The graben is filled with several kilometres of sediments; the Black Forest mainly consists of crystalline rocks. In the transition or foothill zone (German: Vorbergzone), Mesozoic sedimentary rocks are present below the surface or crop out as ridges and hills, reflecting the fault pattern and tilting of the strata. In this region, the Upper Triassic (Keuper), which is also present

Received: 27 January 2009 / Accepted: 17 March 2009

Published online: 27 March 2009

(C) Springer-Verlag 2009

N. Goldscheider (-

Centre of Hydrogeology (CHYN),

University of Neuchâtel,

Rue Emile-Argand 11, 2009, Neuchâtel, Switzerland

e-mail: nico.goldscheider@unine.ch

Tel.: +41-32-7182645

T. D. Bechtel

Department of Earth \& Environmental Sciences,

University of Pennsylvania,

254-B Hayden Hall, 240 South 33rd Street, Philadelphia,

PA 19104-6316, USA below Staufen, includes gypsum and anhydrite layers and lenses of substantial thickness, which is common knowledge and documented in publications and geologic maps. Even a standard German-language textbook entitled Geologie von Mitteleuropa (Geology of Central Europe) mentions noteworthy anhydrite occurrences in this region (Walter 1992).

Anhydrite transforms into gypsum when it comes in contact with water, resulting in a volume increase of up to $61 \%$ that can generate pressures of $5-10 \mathrm{MN} / \mathrm{m}^{2}$. Geotechnical engineering books, including traditional German textbooks, discuss this problem and recommend avoiding any contact between anhydrite and groundwater in all types of construction activities (Prinz 1991). There are numerous well-studied examples, internationally and in southwest Germany, where swelling of anhydrite caused severe geotechnical problems during construction of roads, tunnels or buildings. In the USA alone, an oftcited study by Jones and Holtz (1973) calculated that shrinking or swelling materials inflicted at least \$2.3 billion USD annually in damage to houses, buildings and roads.

This geologic and geotechnical knowledge appears to have been ignored during the Staufen project, and a predictable disaster has run its course. In late 2007, seven boreholes, up to $140 \mathrm{~m}$ deep, were drilled into the gypsumand anhydrite-bearing Keuper formations, creating hydraulic contact between anhydrite and confined groundwater. The boreholes were cased in the uppermost part, while the deeper parts remained uncased. A few weeks after drilling, cracks started to form in nearby buildings. Geodetic measurements soon revealed that the ground was rising. Since then, the impacted area has increased steadily; 131 houses are currently affected, with some houses seriously damaged (Fig. 2). The highest uplift exceeds $1 \mathrm{~cm} / \mathrm{month}$, with no signs yet of slowing. The uplift rate and the degree of damage generally decrease with increasing distance from the drillings (statement to the press, released in December 2008 on the website of Staufen, www.stadt-staufen.de).

One type of crack is particularly prominent and frightening: vertical, open cracks that seem to be oriented towards the area of the drillings and tend to cut the impacted buildings from the ceiling to the roof (Fig. 3). It is conceptualised that these types of radially divergent, vertical cracks also exists underground, caused by serious swelling of a cylindrical zone around the drillings. At the 


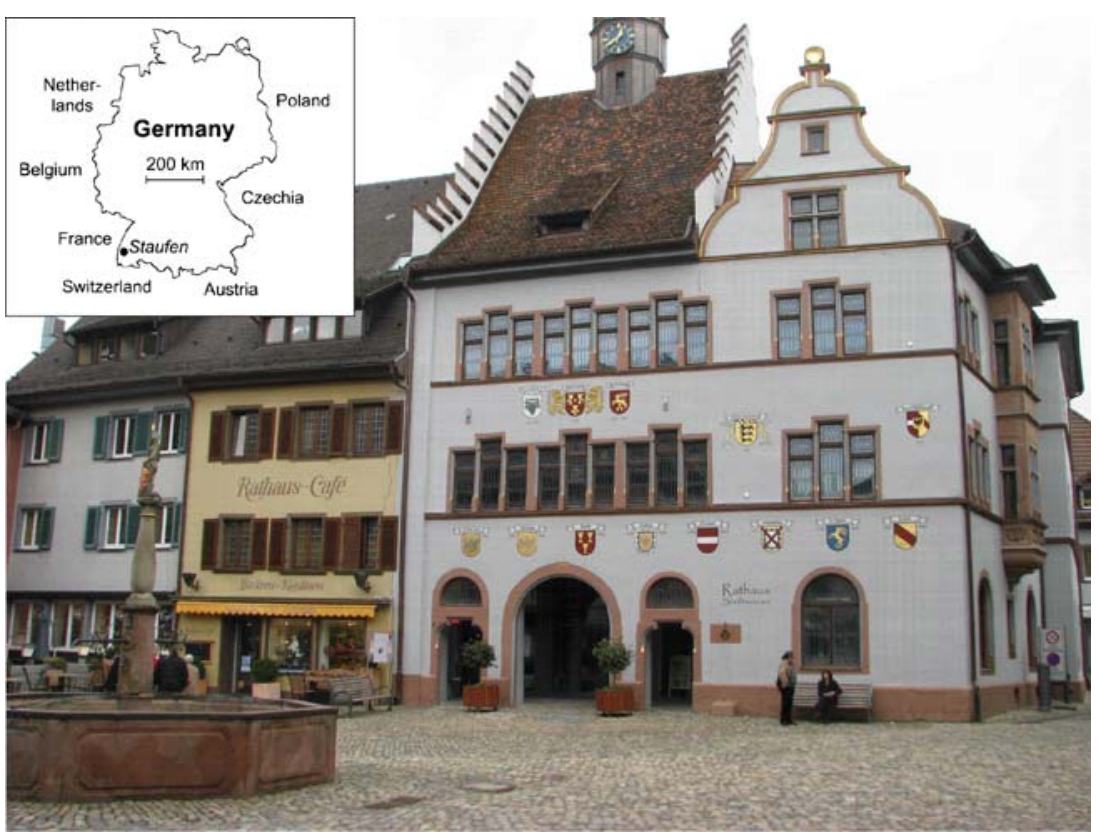

Fig. 1 Location of the town of Staufen and impression of the historic town hall in the city centre

current level of understanding of the problem, one can only hope that the lithostatic/hydrostatic pressures and material strengths at depth do not allow for the opening of these cracks, which would further expose anhydrite to groundwater.

Despite the strict correlation between the time and place of the drillings and the time and place of uplift and damage, an expert report $(\mathrm{H}$. Schad, MPA Stuttgart, 19 September 2008, prepared for the Regional Court of Freiburg) states that natural geologic movements at faults may also have caused this phenomenon, by changing the previous flow system so that groundwater suddenly entered the anhydrite; according to this report, the probability of natural causes versus the drillings is $1: 2$. This estimate is asserted without justification. The report

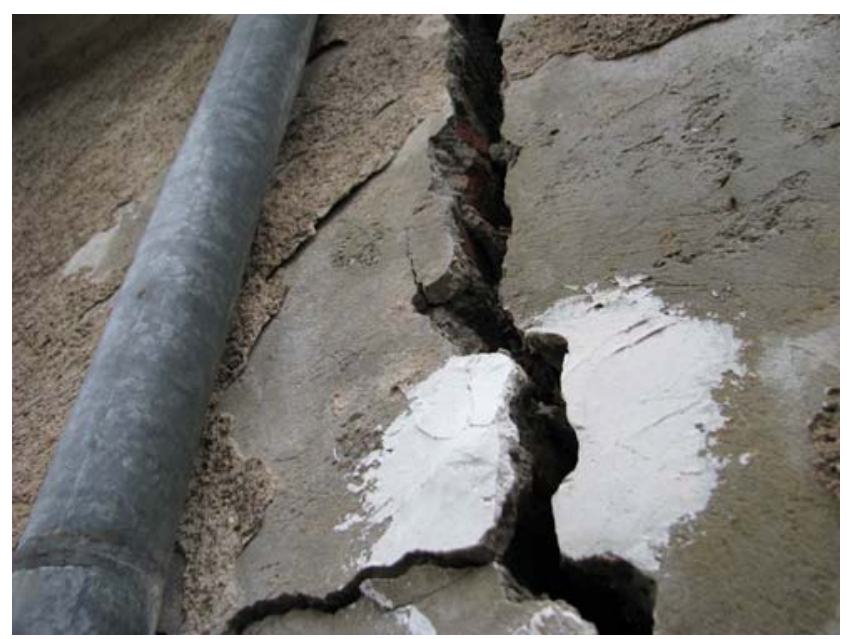

Fig. 2 One of the largest cracks (rainwater gutter for size comparison) in the city centre of Staufen also states that the drillings were accomplished in accordance with "state of the art" drilling techniques, and that no additional requirements would have been necessary.

One can only speculate how such statements found their way into an expert report, but they are indefensible. Firstly, natural geologic movements, strong enough to alter the groundwater flow system abruptly, would have associated seismic activity, i.e. a significant earthquake in

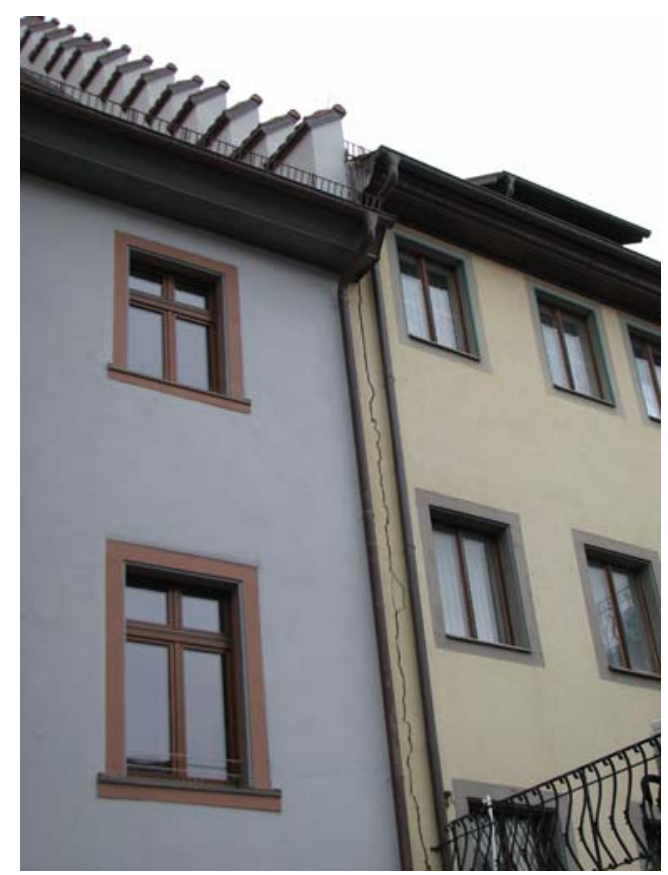

Fig. 3 Vertical open crack in the city centre that cuts two buildings from the ceiling to the roof 
late 2007, centred in Staufen. However, there was no such earthquake. Secondly, assuming that such phenomena are possible without seismic activity (an assumption without precedent), the probability that they would naturally occur precisely at this time and at this place would still not be 1:2 but, based on rough assumptions, less than "one-in-amillion". Thirdly, it is undoubtedly no comfort to the homeowners to learn that the drillings represent the state of the art; and, if this is the state of the art for geothermal drilling, clearly something must be wrong with it.

All this is not only a disaster for the historic town of Staufen, but is also likely to discredit the use of geothermal energy. Several lessons can and should be learned:

1. Although geothermal energy is a safe and renewable energy with a great potential in general, it also has its technical and economic limitations and associated risks (albeit less than other forms of energy production, including other renewable energies). These limitations and risks should be investigated, evaluated, discussed and communicated forthrightly.

2. Geologic and hydrogeologic expertise is indispensable in the process of planning, authorising and implementing large geothermal installations. This expertise should include essential competency in mineralogy, stratigraphy and structural geology as well as an understanding of groundwater occurrence and flow, and groundwater-rock interactions.
3. More and better training and education are required.

The authors of this article have had no involvement in the Staufen case, but describe it from a distance, as outside observers astonished at an avoidable disaster (that, in the interests of full disclosure, damaged a beautiful town in the region of the first author's native home), based on available information and personal observations. It would be interesting to read a detailed study on this case quite soon, as well as a general evaluation on the possible impacts of geothermal installations on infrastructure, the environment and water resources, and how to avoid or minimise these impacts, a need that has recently also been expressed by Ferguson (2009).

\section{References}

Ferguson G (2009) Unfinished business in geothermal energy. Ground Water 47(2):167

Jones D, Holtz R (1973) Expansive soil: the hidden disaster. Civil Eng ASCE 43(8):49-51

Prinz H (1991) Abriss der Ingenieurgeologie [Introduction to geotechnical engineering], 2nd edn. Enke, Stuttgart, Germany, $466 \mathrm{pp}$

Seyboth K, Beurskens L, Langniss O, Sims REH (2008) Recognising the potential for renewable energy heating and cooling. Energ Pol 36(7):2460-2463

Walter R (1992) Geologie von Mitteleuropa [Geology of Central Europe]. Schweizerbart, Stuttgart, Germany, $561 \mathrm{pp}$ 